\title{
Perancangan dan Implementasi WSN (Wireless Sensor Network) Pada Alat Ukur Energi Listrik
}

\section{Design and Implementation of WSN (Wireless Sensor Network) on Electrical Energy Measuring Instruments}

\author{
Aprinal Adila Asril, Firdaus, Arsis Warman \& Rahmifa Hendri \\ Jurusan Teknik Elektro Politeknik Negeri Padang Kampus Limau Manis Padang 25163 \\ Telp.0751-72590 Fax.0751-72576 Email: aprinal@pnp.ac.id
}

\begin{abstract}
WSN (Wireless Sensor Network) is a network consisting of several sensor nodes that form a collaboration in a WSN technology network using sensors. The WSN system can be implemented on an electrical energy meter. Electrical energy measuring instrument ( $k w h$ meter) is important for the community because it is related to the amount of the electricity bill. In the use of electrical energy, sometimes people do not know how much energy has been used in a month, so there is often a waste of electricity. The main purpose of this system is in the framework of transparency and provides information on per-kWh load rates in the use of electricity.

The method used in making WSN implementation on this electrical energy measuring instrument is analyzing the problem, designing the system, making the system up to system testing. By carrying out these steps, the WSN implementation on this electrical energy measuring instrument can provide monitoring effectiveness and can find out how much per- $k$ Wh costs in the use of electrical energy.

This system is programmed using the C language on Arduino. The devices used are Arduino Nano as the main controller, nRF24L01, ZMCT103C, LM358, LM2917N, and RTC. From the discussion it can be concluded that this system can help in knowing the cost of electricity usage per-kWh and can monitor the use of electrical energy using a PC (Personal Computer).
\end{abstract}

Keywords: Wireless Sensor Network, Arduino Nano, Electrical Energy Measuring Instrument

\section{PENDAHULUAN}

Wireless Sensor Network (WSN) telah mendapatkan popularitas dalam berbagai komunitas riset karena pada sistem WSN ini menyediakan infrastruktur yang menjanjikan untuk berbagai aplikasi kontrol dan pemantauan. Jaringan sederhana dan murah ini memungkinkan proses pemantauan dilakukan dari jarak jauh secara real-time. WSN merupakan suatu jaringan wireless yang terdapat beberapa node yang bisa melakukan komunikasi lansung antara node satu dengan node lainnya dan dapat di aplikasikan dimanapun. Sistem WSN ini telah banyak dibuat dan diteliti oleh peneliti-peneliti sebelumnya contohnya yaitu, alat untuk Perancangan Jaringan Sensor Nirkabel Memantau Suhu dan Kelembaban menggunakan nRF24L01+ [1], alat untuk Algoritma Deteksi Dini Kebakaran Hutan
Berdasarkan Jaringan sensor Nirkabel [1], dan lain-lain.

Alat ukur energi listrik (kwh meter) penting bagi masyarakat karena berkaitan dengan besarnya biaya tagihan listrik. Dalam pemanfaatan energi listrik terkadang masyarakat tidak mengetahui berapa banyak jumlah energi yang telah digunakan dalam sebulan sehingga sering terjadi pemborosan energi listrik. Hal ini banyak dirasakan oleh masyarakat yang memiliki sebuah rumah kos misalnya. Di setiap rumah kos memiliki penghuni yang banyak dan bervariasi kebutuhan energi listriknya. Jika cara konvensional dengan menyeragamkan besarnya iuran listrik perbulan tentu ini tidak efektif dan tidak adil terhadap kedua belah pihak.

Apabila di setiap kamar kos diberikan satu unit kwh meter PLN, maka hal ini akan 
dapat memakan biaya yang cukup besar karena biaya pemasangan alat ukur tersebut cukup mahal, mulai dari harga minimal Rp.421.000/unit hinga harga maximal Rp.152.675.000/unit [12]. Harga tersebut sesuai dengan daya yang tersambung atau tergantung kepada kebutuhan pelanggan Berdasarkan hal tersebut diatas, dibuatlah alat ukur energi listrik yang murah dari segi perangkatnya, kompatibel, dan penggunaannya tidak melanggar hukum. Setiap individu alat ukur akan mengirimkan data nirkabel ke satu unit pengumpul (logger) yang digunakan tidak hanya untuk memantau energi listrik(wH) alat ini juga mengukur parameter lainnya seperti Tegangan(V), Arus(I), Frekuensi(Hz), Daya Semu(VA), Daya Reaktis(VAR), Daya Aktif(w), Factor Daya dan biaya yang harus dibayar(Rp), sehingga dari latar belakang diatas maka penulis membuat alat yang berjudul "Perancangan Dan Implementasi WSN (Wireless Sensor Network) Pada Alat Ukur Energi Listrik.".

Adapun tujuan dari pembuatan penelitian yang diharapkan penulis adalah:

1. Mengimplementasikan sistem WSN untuk memonitoring penggunaan energi listrik pada alat ukur energi listrik.

2. Membangun komunikasi antar node pada WSN.

3. Menanampilkan parameter-parameter energi listrik serta tagihan penggunaan energi listrik dalam satuan rupiah pada LCD

Manfaat dari pembuatan penelitian ini adalah:

a. Mempermudah kinerja pemilik rumah kos-kosan dalam megontrol penggunaan listrik oleh penghuni kos.

b. Penghuni kos dapat mengetahui biaya tagihan energi listrik yang digunakan selama satu bulan pemakaian.

c. Pemilik kos tidak perlu lagi meminta tagihan ke tiap-tiap kamar penghuni, dengan adanya alat ini pemilik kos dapat memonitoring dan mengontrol pemakaian energi listrik penghuni melalui komputer, apabila ada yang menunggak maka pemilik kos bisa langsung mematikan listrik si penghuni tanpa ada pemberitahuan sebelumnya

\section{METODOLOGI}

\section{Arsitektur Dasar Wireless Sensor Network (WSN)}

Pada dasarnya arsitektur WSN hanya terdiri dari beberapa node sensor yang dapat saling berkomunikasi satu sama lain. Komunikasi antar node dapat melakukan pertukaran data dimana setiap node sensor saling terhubung satu sama lain secara Ad Hoc dan mendukung komunikasi Multi Hop. Ad Hoc merupakan suatu fungsi dimana sebuah node sensor dapat melakukan komunikasi satu sama lain secara langsung tanpa ada perantara infrastruktur jaringan lain seperti router atau akses point, karena pada node sensor dapat berperan sebagai router atau perangkat perantara (Intermediate). Berikut bentuk ilustrasi dari tiga buah node sensor yang saling terhubung satu sama lain.

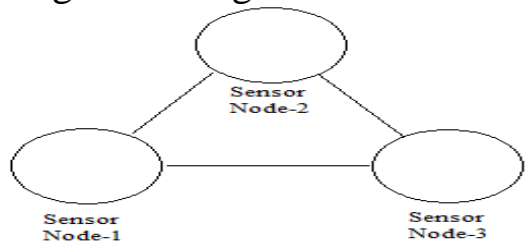

Gambar.1. Arsitektur WSN dengan 3 buah Node Sensor yang saling terhubung

WSN juga memiliki kemampuan Multi Hop, dimana setiap node sensor dapat mengirim data ke node sensor lain dengan menggunakan node sensor yang ada di tengahnya sebagai perantara (berperan sebagai router).WSN dapat terdiri dari banyak sensor node dengan minimal sebuah Sink Node. Sink Node berperan sebagai ujung dari sistem pada jaringan milik WSN berbasis Ad Hoc. Sink Node berperan sebagai pengumpul data (data collector) atau sebagai gateway (pintu gerbang) ke jaringan public (internet). Sink Node juga berperan sebagai penyebar paket dari perangkat atau sistem lain ke WSN, 
misalkan untuk keperluan pengendalian atau konfigurasi sensor node secara remote.[1]

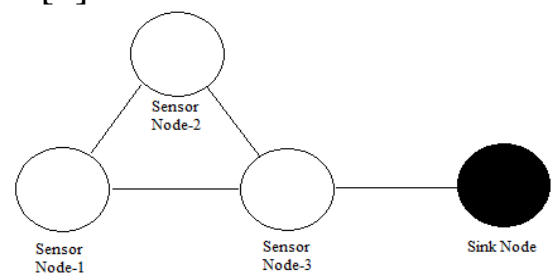

Gambar.2. WSN dengan Sink Node [2]

\section{Komponen Utama Node Sensor pada WSN}

Sebuah node sensor memiliki enam buah komponen utama untuk dapat menjalankan fungsinya dengan baik sebagai berikut:

a. Sensor

Sensor merupakan perangkat elektronik yang bertugas melakukan pemindaian pada sebuah lingkupan ataupun objek fisik untuk kemudian menghasilkan data-data hasil pemindaian yang dapat diolah menjadi informasi. Sensor tidak dapat bekerja tanpa adanya ADC (Analog to Digital Converter) dimana ADC akan mengubah sinyal analog menjadi sinyal digital.

\section{b. Transceiver}

Transceiver merupakan suatu komponen elektronik yang memadukan komponen transmitter dan receiver, untuk dapat melakukan fungsi transmisi dan penerimaan sinyal. Pada node sensor transceiver membantu tugas dari controller, terkait dengan sinyal analog dan sinyal digital dari hasil pemindaian oleh node sensor yang dilakukan oleh sensor.

\section{c. External memory}

Merupakan memory tambahan yang diperlukan untuk penyimpanan data-data hasil pemindaian maupun penyimpanan proses dan eksekusi oleh program( aplikasi) dan sistem operasi (program memori).

\section{d. Controller}

Controller merupakan perangkat yang berfungsi untuk melakukan pemorosesan data, kontrol kendali terhadap fungsi dari komponen lainnya pada nod sensor, serta menampilkan tugas-tugas yang dikerjakan oleh komponen lainnya pada node sensor dan dan node sensor itu sendiri.

e. Power Source

Power source merupakan sumber energy listrik tambahan bagi node-node sensor pada WSN. Sebagaimana yang telah diketahui bersama, sumber daya (resource) energy pada WSN (pada node sensor) bersifat sangat terbatas dangan hanya menghandalkan sumber dari batrai, untuk itu diperlukan adanya sumber energy listrik tambahan terutama untuk daerah yang sulit menemukan sumber energy listrik.

f. Analog to Digital Converter (ADC)

ADC merupakan papan elektronik yang berfungsi untuk merubah (convert) sinyal analog ke dalam bentuk sinyal digital. Hal ini sebabkan karena inputan pada transducer pada node sensor berupa sinyal analog yang harus diubah kedalam bentuk sinyal digital. Apabila sudah dirubah menjadi sinyal digital maka akan diteruskan ke controller untuk diproses dan disimpan ke server atau database.[1]

\section{Modul Komunikasi Wireless nRF24L01}

NRF24L01 adalah tranceiver $2.4 \mathrm{GHz}$ chip tunggal dengan mesin protokol baseband tertanam yang cocok untuk aplikasi nirkabel berdaya rendah. nRF24L01 dirancang untuk operasi di pita frekuensi ISM di seluruh dunia pada 2.400$2.4835 \mathrm{GHz}$. untuk mendesain sistem radio dengan nRF24L01, Anda cukup membutuhkan MCU (mikrokontroler) dan beberapa komponen pasif eksternal. Anda dapat mengoperasikan dan mengkonfigurasi nRF24L01 melalui Interface Serial Peripheral (SPI). Peta daftar, yang dapat diakses melalui SPI, berisi semua register konfigurasi dalam nRF24L01 dan dapat diakses di semua mode operasi chip .Mesin protokol baseband emmbedded didasarkan pada komunikasi paket dan mendukung 
berbagai mode dari operasi manual untuk operasi protokol otonom canggih. FIFO internal memastikan kelancaran aliran data antara ujung depan radio dan MCU sistem. Enhanced ShockBurst mengurangi biaya sistem dengan menangani semua operasi lapisan tautan berkecepatan tinggi.

Ujung depan radio menggunakan modulasi GFSK. ini memiliki parameter yang dapat dikonfigurasi pengguna seperti saluran frekuensi, daya output dan laju data udara. nRF24L01 mendukung kecepatan data udara $250 \mathrm{kbps}, 1 \mathrm{Mbps}$ dan 2Mbps. laju data udara yang tinggi dikombinasikan dengan mode penghematan daya teo membuat nRF24L01 sangat cocok untuk desain daya ultra rendah. NRF24101 jatuh kompatibel dengan nrf24101 dan di udara yang kompatibel dengan nrf24101A, nrf24102, nrf24E1 dan nRf24E2. nilai pemblokiran intermodulation dan wideband di nrf24101 + telah meningkatkan margin untuk memenuhi standar regulasi RF. regulator tegangan internal memastikan Rasio Penolakan Pasokan Daya tinggi (PSRR) dan rentang catu daya yang luas. Modul NRF24L01 dapat ditunjukan pada Gambar.3.[3]

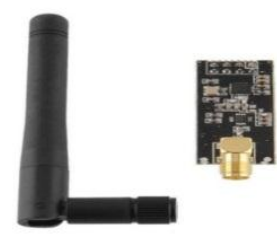

Gambar.3. Modul nRF24L01 [3]

\section{Arduino Nano}

Arduino merupakan board sistem minimum mikrokontroler yang mempunyai sifat open source. Board Arduino ini menggunakan IC mikrokontroler AVR yang merupakan produk dari Atmel.

Pada Arduino Nano digunakan IC mikrokontroler ATmega 328 (Arduino Nano3.x) atau ATmega 168 (Arduino Nano 2.x). Selain bersifat open source Arduino juga memiliki bahasa pemprograman sendiri berupa bahasa C. Arduino Nano memiliki DC power jack, port USB Mini-B yang digunakan untuk upload source code program ke dalam mikrokontroler.

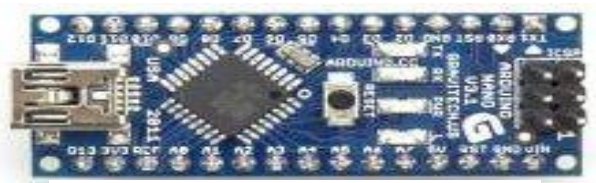

Gambar.4. Arduino Nano[4]

\section{Modul Bluetooth HC-05}

Pada perancangan skripsi ini dibutuhkan koneksi antara android smartphone dengan mikrokontroler secara nirkabel, maka digunakan media Bluetooth sebagai sarana komunikasi. Modul Bluetooth yang digunakan adalah tipe HC05. Modul Bluetooth HC-05 merupakan modul Bluetooth yang dapat diatur sebagai master atau slave. Mode master adalah mode dimana Bluetooth dapat berfungsi sebagai pengirim dan penerima data, sedang mode slave Bluetooth hanya dapat berfungsi sebagai penerima saja. Modul Bluetooth HC-05 dapat ditunjukan pada Gambar.5 berikut.[4]

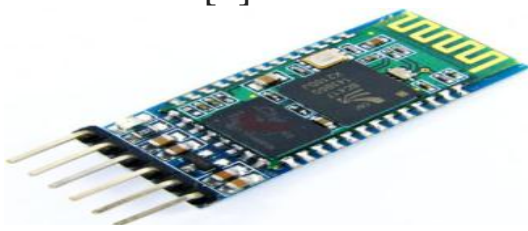

Gambar.5. Modul Bluetooth HC-05[4]

\section{Serial RTC (Real Time Clock) DS3231}

RTC merupakan alat yang digunakan untuk mengakses data waktu dan kalender. RTC yang digunakan adalah DS3231 yang merupakan pengganti dari serial RTC tipe DS1307 dan DS1302. RTC mampu mengakses informasi data waktu mulai dari detik, menit, jam, hari, tanggal, bulan dan tahun. Akhir tanggal pada setiap bulan akan disesuaikan secara otomatis dengan kurang dari 31 hari dan juga mampu mengoreksi tahun kabisat. Pada DS3231 Operasi jam bisa diformat dalam 24 jam atau 12 jam (AM/ PM). Untuk tatap muka dengan suatu mikroprosesor dapat disederhanakan dengan menggunakan sinkronisasi komunikasi serial I2C dengan kecepatan clock 400Khz. Hanya 
membutuhkan 2 saluran untuk komunikasi dengan clock/RAM: SCL (serial clock), SDA (Serial I/O data), dan juga dilengkapi dengan keluaran SQW/Out yang dapat deprogram untuk mengetahui perubaaan data waktu pada RTC dan pin RST. DS3231 didesain untuk mengoperasi pada power yang sangat rendah dan mempertahankan data dan informasi waktu \pm 1 microwatt.

Adapun karakteristik dari RTC tipe DS3231 yaitu:

- RTC menghitung detik, menit, jam, tanggal, bulan, hari setiap minggu dan tahun dengan benar sampai tahun 2100

- Serial I2C untuk pin minimum proses komunikasi RTC

- $\quad 2.0$ - 5.5 Volt full operation

- Mempunyai kemasan 16 pin SOICs

- 3 simple wire interface ( I2C dan SQW/Out)

- Square wave output yang dapat deprogram

- Mempunyai sensor temperatur dengan akurasi \pm 3 Celcius.

Adapun konfigurasi pin dari RTC DS3231 ditunjukkan sebagaimana gambar.6.[5]

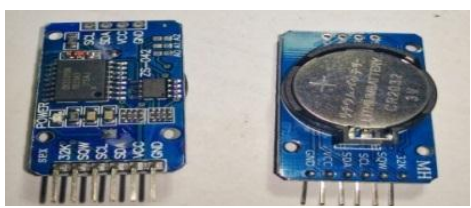

Gambar.6. RTC DS3231[5]

\section{Sensor Arus}

ACS712 merupakan suatu IC terpaket yang mana berguna sebagai sensor arus menggantikan transformator arus yang relative besar dalam hal ukuran. Pada prinsipnya ACS712 sama dengan sensor efek hall lainnya yaitu dengan memanfaatkan medan magnetik disekitar arus kemudian dikonversi menjadi tegangan yang linier dengan perubahan arus. Nilai variabel dari sensor inimerupakan input untuk mikrokontroler yang kemudian diolah. Keluaran dari sensor ini masih berupa sinyal teganganAC, agar dapat diolah oleh mikrokontroler maka sinyal tegangan AC ini di searahkan oleh rangkaian penyearah. Module sensor arus dan rangkaian sensor arus dapat ditunjukan pada Gambar.5 dan Gambar.7.

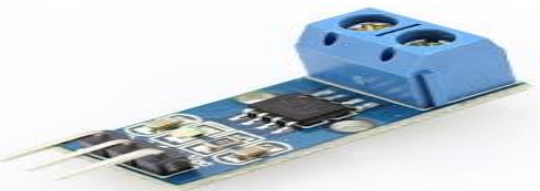

Gambar.7. Module Sensor Arus

\section{Komunikasi Serial}

Komunikasi serial ialah pengiriman data secara serial (data dikirim satu persatu secara berurutan), sehingga komunikasi serial lebih lambat dari pada komunikasi paralel. Komunikasi Serial dapat digunakan untuk menggantikan komunikasi parallel jalur data 8-bit dengan baik. Tidak saja memakan biaya yang lebih murah, namun dapat digunakan untuk menghubungkan dua peralatan yang sangat jauh misalnya menumpang pada kabel telpon.

Agar komunikasi serial dapat bekerja dengan baik, data byte harus diubah ke dalam bit-bit serial menggunakan peralatan yang disebut shift register parallel-in serialout, kemudian data dikirimkan hanya dengan satu jalur data saja. Hal yang serupa dikerjakan pada penerima, dimana penerima harus mengubah bit-bit serial yang diterimanya menjadi data byte yang persis seperti data semula pada pengirim, dengan menggunakan shift register serial-in parallel-out. Tentu saja jika data serial tersebut dikirim menumpang jalur telpon, maka dibutuhkan peralatan pengubah status digital $0 \mathrm{~s}$ atau $1 \mathrm{~s}$ menjadi sinyal suara audio. Peralatan seperti ini kemudian disebut modem (modulator/demudulator). Modulator sebagai pengubah sinyal digital menjadi sinyal audio, sebaliknya demodulator adalah sebagai mengubah kembali sinyal audio menjadi sinyal digital. Pada jarak yang sangat dekat, kita dapat menggunakan komunikasi serial sederhana dan tidak perlu modulasi. Seperti yang dapat kita lihat pada hubungan komputer kita dengan keyboard atau mouse. 


\section{Prinsip Pengukuran Parameter Listrik}

\section{Daya Rata-Rata}

Tenaga listrik adalah produk tegangan dan arus. ADC memberikan input sinyal analog tegangan dan arus di bentuk sampel digital. Akumulasi voltase (V [n]) dan arus (I [n]) sampel produk dari waktu ke waktu dan kemudian membagi total nilai akumulasi dengan jumlah sampel (N) memberikan daya rata-rata yang dapat dilihat pada persamaan 1 berikut.

Daya rata-rata $=\frac{\sum_{n=0}^{N-1}\left(V[n]^{*} I[n]\right)}{N}$

Untuk arus bolak-balik, daya rata-rata juga harus memperhitungkan faktor daya, yaitu hubungan fase antara tegangan dan arus Daya $\mathrm{AC}$ aktif adalah $\mathrm{V} * \mathrm{I} * \cos \theta$, di mana $\mathrm{V}$ dan $\mathrm{I}$ adalah tegangan dan arus RMS, dan $\theta$ adalah fasa sudut antara keduanya. Nilai sudut fasa pada dasarnya tertanam pada sampel tegangan dan arus. Oleh karena itu, perhitungan sudut fase sebenarnya mungkin hanya diperlukan untuk tujuan menghitung dan menampilkan daya faktor.

\section{Perhitungan Energi}

Hal ini diperlukan untuk melakukan pengukuran yang sering dilakukan untuk mendapatkan nilai konsumsi energi sistem $\mathrm{AC}$ yang akurat. Itu sampling rate Fs harus berkali-kali dari frekuensi suplai. Jika $\mathrm{N}$ adalah sampel total dalam detik N / Fs, Energi masuk Istilah watt detik dapat diperoleh dengan mengalikan $\mathrm{N} /$ Fs dengan daya rata-rata dapat ditujukan pada persamaan 2 berikut

$$
\text { Energi } \quad=\frac{\sum_{n=0}^{N-1}\left(V[n]^{*} I[n]\right)}{F_{s}}
$$

\section{Perhitungan Tegangan dan Arus}

Nilai RMS didefinisikan sebagai akar kuadrat dari nilai rata-rata kuadrat nilai seketika a kuantitas bervariasi secara berkala, dirata-ratakan dalam satu siklus yang lengkap. Persamaan waktu diskrit untuk menghitung Vrms adalah sebagai per yang dapat ditunjukan pada persamaan 3 berikut.

$$
V_{r m s}=\sqrt{\frac{\sum_{n=0}^{N-1}(V[n] * V[n])}{N}}
$$

I rms dihitung dengan menggunakan persamaan yang sama dengan mengganti sampel saat ini, I [n] sebagai gantinya $\mathrm{V}$ [n].

\section{Perhitungan Daya Nyata dan Daya faktor}

Daya nyata dapat dihitung dengan mengalikan voltase sesaat dan arus sesaat sesuai Persamaan 4.

$$
\text { Daya nyata }=V_{r m s} * I_{r m s}
$$

Daya faktor dapat diturunkan dari daya rata-rata dan daya nyata sesuai persamaan 5 berikut.[7]

$$
\text { Power Faktor }=\frac{\text { Daya Rata }- \text { Rata }}{\text { Daya } \text { nyata }}
$$

\section{Perancangan dan Pembuatan Sistem}

Perancangan ini dilaksanakan melalui tiga tahapan penting, yaitu perangkat keras hardware, perangkat lunak software, dan bagian mekanik. Secara garis besar bagian hardware terdiri dari rangkaian node sensor dan rangkaian node indikator, sedangkan untuk software terdiri dari perancangan flowchart dan listing program. Sedangkan untuk mekanik terdiri dari perancangan PCB dan miniatur. Sebelum merancang perangkat keras terlebih dahulu harus merancang sistem berupa blok diagram dan sistem kerja dari keseluruhan alat.

\section{Blok Diagram Sistem}

Blok diagram merupakan suatu pernyataan gambar yang ringkas dari gabungan sebab dan akibat antara masukan dan keluaran dari suatu sistem. Blok diagram dapat mempermudah dalam menjelaskan prinsip kerja alat yang akan dibuat. Secara umum bentuk blok diagram 
dari sistem kerja perancangan dan implementasi Wireless Sensor Network (WSN) pada alat ukur energi listrik dapat ditunjukan pada gambar 7 .

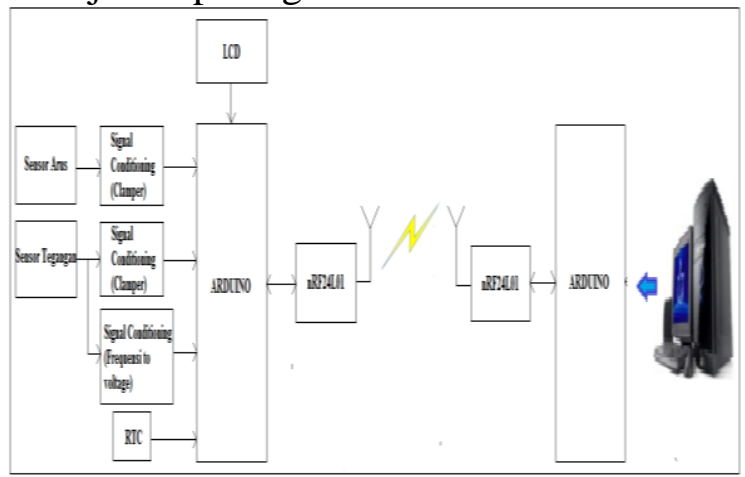

Gambar.8. Blok Diagram Sistem

Perancangan Hardware (Perangkat

Keras)

\section{Rangakaian Sensor Arus}

ZMCT103C merupakan suatu IC terpaket yang mana berguna sebagai sensor arus menggantikan transformator arus yang relatif besar dalam hal ukuran. Pada prinsipnya ZMCT103C sama dengan sensor efek hal lainnya yaitu dengan memanfaatkan medan magnetik disekitar arus kemudian dikonversi menjadi tegangan yang linier dengan perubahan arus. Kemudian di lakukan penguatan pada sinyal menggunakan IC LM 358 yang menghasilkan sinyal baik yang linier maupun non linier terutama dalam sistem pengaturan dan pengendalian analog. Nilai variabel dari sensor ini merupakan input untuk mikrokontroler yang kemudian diolah. Keluaran dari sensor ini masih berupa sinyal tegangan AC, agar dapat diolah oleh mikrokontroler maka sinyal tegangan AC ini di searahkan menggunakan signal conditioning. Gambar 10 merupakan gambar sensor arus.

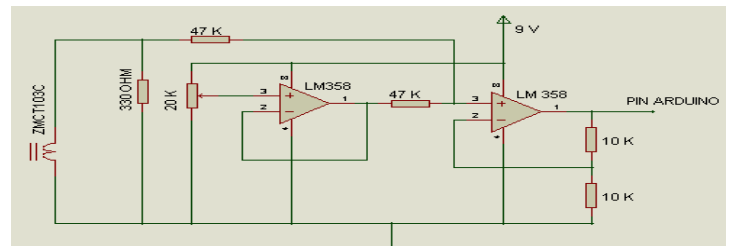

Gambar.9. Skematik Rangkaian Sensor Arus

\section{Rangkaian Sensor Tegangan}

Sensor tegangan menggunakan transformator tegangan sebagai penurun tegangan dari 220 ke 5 Volt AC kemudian disearahkan menggunakan signal conditioning untuk mengubah tegangan $\mathrm{AC}$ ke tegangan DC, kemudian di filter setelah itu masuk kerangkaian pembagi tegangan untuk menurunkan tegangan, tegangan yang dihasilkan tidak lebih dari 5 Volt DC sebagai inputan ke mikrokontroler. Kemudian untuk penguatan pada sinyal digunakan IC LM 358 yang menghasilkan sinyal baik yang linier maupun non linier terutama dalam sistem pengaturan dan pengendalian analog.

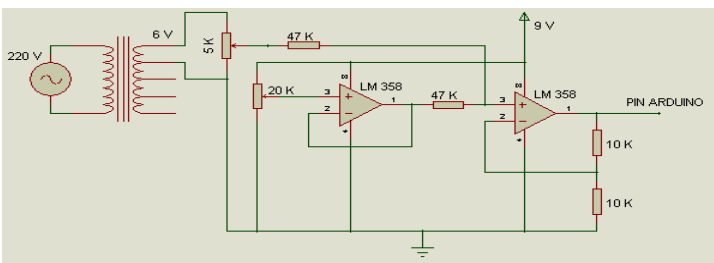

Gambar.10. Skematik rangkaian Sensor Tegangan

\section{Rangkaian Sensor Frekuensi ke Tegangan}

LM2917 di desain khusus sebagai pengubah frekuensi menjadi tegangan. LM2917 mampu memberikan output 0 volt seketika pada waktu frekuensi berubah 0 Hz. LM2917 membutuhkan konfigurasi RC dalam doubling frekuensi dan memiliki zener regulator internal untuk menghasilkan akurasi dan stabilitas dalam proses konversi frekuensi ke tegangan. Sensor ini mendeteksi setiap perubahan frekuensi pada generator. Frekuensi yang terdapat dalam tegangan AC masuk ke sensor frekuensi akan dikonversikan ke dalam bentuk tegangan DC, yang kemudian akan masuk ke analog input pada mikrokontroler. Sinyal analog akan dikonversi menjadi nilai digital dengan ADC pada mikrokontroler sehingga dapat diproses dengan metode yang telah ditentukan dalam mikrokontroler. Tegangan DC yang dihasilkan mewakili frekuensi yang terbaca. 


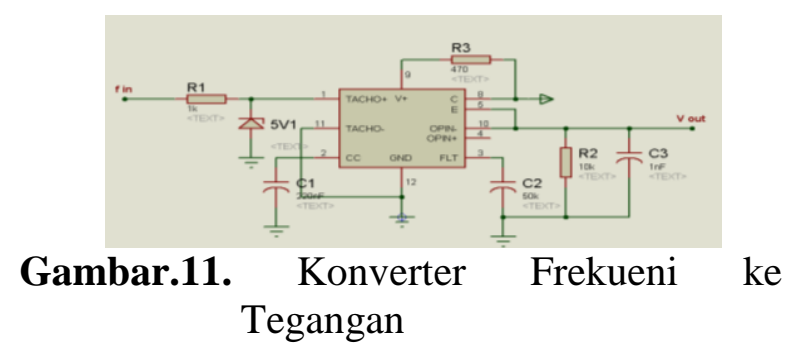

Rangkaian Node Indikator

Rangkaian node indikator akan menerima data dari node sensor yang berperan sebagai transceiver. Data yang diterima akan diolah oleh mikrokontroler dan data tersebut akan diteruskan ke komputer.

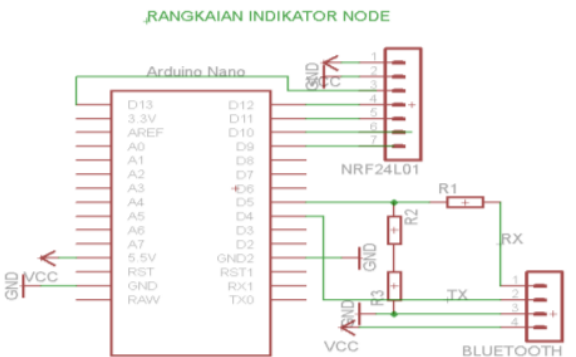

Gambar.12. Rangkaian Node Indikator

\section{Pembuatan Hardware}

Sebelum membuat perangkat keras terlebih dahulu harus merancang sistem berupa diagram blok dan sistem kerja dari keseluruhan alat. Diagram blok merupakan suatu pernyataan gambar yang ringkas dari gabungan sebab dan akibat antara masukan dan keluaran dari suatu sistem. Blok diagram dapat mempermudah dalam menjelaskan prinsip kerja alat yang akan dibuat. Secara umum bentuk blok diagram dari sistem kerja perancangan dan implementasi Wireless Sensor Network (WSN) pada alat ukur energi listrik dapat ditunjukan pada gambar 13 .

Pada blok diagram pada gambar 13, perancangan dan implementasi WSN pada alat ukur energi listrik menggunakan dua buah node sensor dan satu buah node master. Dalam node sensor memiliki tiga masukan (input) yaitu sensor arus, sensor tegangan, dan konverter frekuensi ke tegangan. Kemudian data masukan akan diteruskan ke board arduino untuk diolah sesuai dengan perintah program. Data tersebut akan ditampilkan pada LCD sebagai output.

Sensor arus berfungsi sebagai pendeteksi nilai arus yang mengalir pada rangkaian. Sensor arus akan mendeteksi arus listrik yang mengalir pada kawat, sedangkan sensor tegangan digunakan untuk mengukur tegangan $\mathrm{AC}$ yang masuk kedalam rangkaian. Sebelum tegangan AC masuk ke rangkaian, tegangan akan diturunkan menggunakan transformator tegangan karena pada mikrokontroler hanya bisa menampung daya inputan sebesar $5 \mathrm{~V}$. Konverter frekuensi ke tegangan akan mendeteksi setiap perubahan frekuensi. Fekuensi yang terdapat dalam tegangan AC masuk ke sensor frekuensi dan akan di konversikan kedalam bentuk tegangan DC yang kemudian akan masuk ke analog input pada mikrokontroler Arduino Nano.

Arduino Nano akan menerima dan mengolah data dimana sinyal analog yang terinput akan di konversikan menjadi nilai digital dengan menggunakan ADC (Analog Digital Converter) pada mikrokontroler. LCD akan menampilkan data yang telah diprogram. Data yang telah diproses pada node sensor akan dikirim ke indikator node dan akan diolah kembali oleh Arduino Nano yang ada pada indikator node untuk ditampilkan pada komputer sebagai interface pengontrolan.

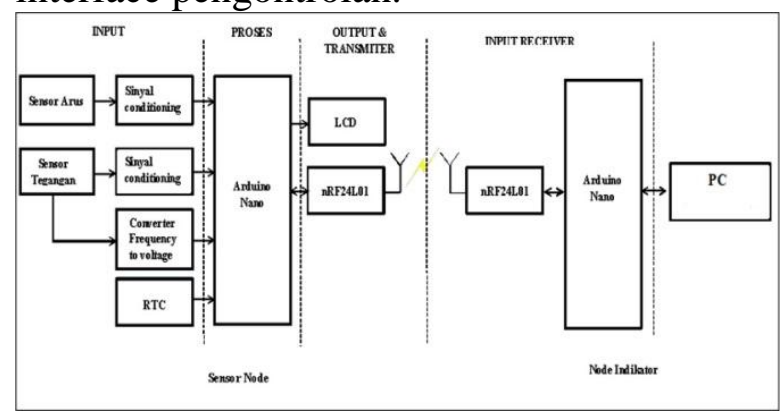

Gambar 13. Diagram Blok Sistem

\section{Perancangan Software}

Setelah melakukan perancangan perangkat keras langkah selanjutnya yaitu melakukan perancangan perangkat lunak dengan membuat sebuah flowchart untuk menentukan bagaimana jalur proses program berjalan. Setelah perancangan selesai, selanjutnya adalah pembuatan 
program dengan menggunakan software Arduino (IDE). Proses pemograman diawali dengan menulis program sumber (source code). Source code kemudian di-compile dan akan menghasilkan kode-kode yang dapat dimengerti oleh mikrokontroler. file dengan ekstensi*.ino ini yang nantinya akan didownload ke mikrokontroler.

Flowchart atau bagan alir adalah bagan (char) yang menunjukan alir (flow) didalam program atau prosedur sistem secara logika. Bagan alir (flowchart) digunakan terutama untuk alat bantu komunikasi dan untuk dokumentasi. Bentuk dari flowchart dapat ditunjukan pada Gambar.14

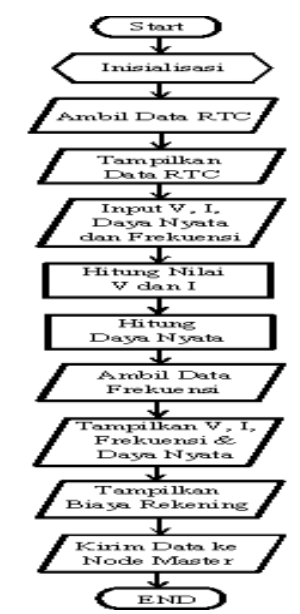

Gambar.14. Flowchart Node Sensor

Pada Gambar.14 merupakan alur kerja dari Sensor Node. Start merupakan sebuah instruksi untuk menandakan mulainya sebuah program. Setelah start maka program akan mengambil data dari modul RTC yaitu berupa data waktu. Setelah itu data RTC akan di tampilkan pada LCD. Langkah selanjutnya yaitu program akan menghitung nilai rms tegangan dan arus yang dihasilkan dari sensor arus dan sensor tegangan. Selanjutnya menghitung daya nyata dan setelah itu mengambil data frekuensi. Kemudian menampilkan data daya nyata, arus, frekuensi, dan tegangan pada LCD. Selanjutnya menampilkan daya total dan biaya rekening pemakaian energy listrik pada LCD. Kemudian data uang telah didapat akan dikirimkan ke komputer.

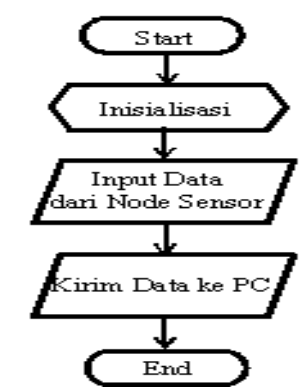

Gambar. 15. Flowchart Indikator Node

Sedangkan Gambar.15 merupakan alur kerja dari Indikator node. Langkah pertama yaitu Start. Kemudian indikator node menerima data dari node sensor, lalu data tersebut akan diteruskan ke komputer dan berakhir

\section{HASIL DAN PEMBAHASAN}

\section{Analisis Sistem}

Pada Alat perancangan dan implementasi Wireless Sensor Network yang telah dibuat menggunakan arduino nano sebagai sistem minimum untuk mengendalikan semua komponenkomponen yang tersimpan pada sistem dan sebagai pengolah data dari input dan akan dikeluarkan melalui output display dan transmitter yang akan mengirimkan data ke receiver. Alat ini bekerja berdasarkan input dan perintah yang telah di program melalalui mikrokontroler,.

Dalam pembuatan alat perancangan dan implementasi Wireless Sensor Network pada alat ukur energi listrik dibuat menggunakan tiga buah input yaitu Sensor Arus, Sensor Tegangan dan Konverter frekuensi ke Tegangan. Sensor arus berfungsi sebagai pendeteksi arus yang mengalir dalam rangkaian elektronika menggunakan ZMCT103c memiliki 1:1000 lilitan medan magnetic disekitar arus kemudian dikonversi menjadi tegangan yang linear dengan perubahan arus. Nilai dari sensor arus akan menjadi input untuk mikrokontroler yang kemudian akan diolah. Mikrokontroler hanya mampu menerima tegangan sebesra 5V. keluaran dari sensor arus ini masih berupa sinyal tegangan AC, untuk dapat diolah oleh mikrokontroler 
maka sinyal tegangan $\mathrm{AC}$ ini di searahkan menggunakan signal conditioning menggunakan LM358. Dimana sinyal AC akan dirubah menjadi sinyal DC dan dikondisikan ke bentuk sinyal sesuai dengan kebutuhan proses selanjutnya.

Sensor tegangan menggunakan transformator tegangan sebagai penurun tegangan dari 220 ke 5 Volt AC kemudian disearahkan menggunakan signal conditioning untuk mengubah tegangan $\mathrm{AC}$ ke tegangan DC, kemudian di filter setelah itu masuk kerangkaian pembagi tegangan untuk menurunkan tegangan, tegangan yang dihasilkan tidak lebih dari 5 Volt DC sebagai inputan ke mikrokontroler. Kemudian untuk penguatan pada sinyal digunakan IC LM 358 yang menghasilkan sinyal baik yang linier maupun non linier terutama dalam sistem pengaturan dan pengendalian analog. Output dari sensor tegangan ini terhubung pada kaki Analog Pin 1 pada mikrokontroler.

Konverter frekuensi ke tegangan yang ditampilkan mengubah frekuensi gelombang yang masuk ke FIN menjadi tegangan yang keluar di $\mathrm{V}$ out pada LM2917. Sinyal yang telah dikonverter kemudian akan masuk ke analog input pada mikrokontroler yang terhubung ke Analog pin 2. Sinyal analog akan dikonversi menjadi nilai digital dengan ADC pada mikrokontroler sehingga dapat diproses dengan metode yang telah ditentukan dalam mikrokontroler. Tegangan DC yang dihasilkan mewakili frekuensi yang terbaca. R3 pada Gambar.12 berfungsi sebagai pembatas arus diode zener internal sedangkan R1 dan D1 sebagai clipper yang akan memotong tegangan negative gelombang sinus dari sekunder transformator step down yang masuk ke FIN dan membentuk gelombang kotak.

Setelah semua data masuk ke mikro maka data tersebut akan diolah dalam bahasa program dengan memasukan rumus parameter-parameter lisrik yang digunakan untuk mendapatkan nilai Tegangan, Arus, Frekuensi, Daya Nyata, Daya Total, dan nilai tarif energi listrik dalam nilai rupiah.
Data parameter-parameter energy listrik tersebut akan di tampilkan pada display.

Setelah menampilkan data node sensor pada LCD maka data tersebut akan dikirim menggunakan modul nRF24L01 sebagai transceiver dan di terima oleh receiver pada node master. Data tersebut akan diolah oleh mikro dan akan dikirim ke PC/laptop.

\section{Analisis Pengujian Sensor Arus}

Pengujian ini bertujuan untuk mengetahui apakah sensor arus dapat melakukan sensing arus dengan baik. Sensor ini dapat mendeteksi arus yang mengalir pada rangkaian elektronika. Berikut merupakan hasil pengujian sensor arus dengan beban yang berbeda-beda dapat dilihat pada gambar 16,dan 17 .

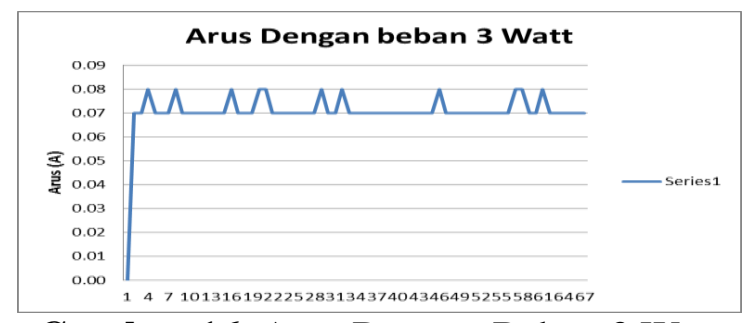

Gambar.16. Arus Dengan Beban 3 Watt

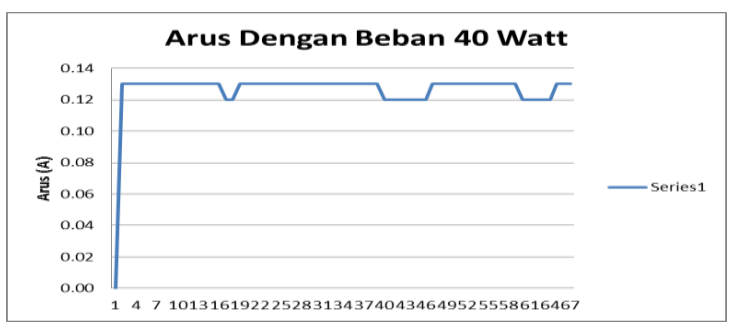

Gambar.17. Arus dengan Beban Lampu 40 watt

Dari gambar 16, 17, dapat dicari dengan menggunakan rumus Daya yaitu

$$
\begin{gathered}
\mathrm{P}=\mathrm{V} \times \mathrm{I} \\
\mathrm{I}=\mathrm{P} / \mathrm{V}=40 / 220=0,18 \mathrm{~A}
\end{gathered}
$$

Dari hasil perhitungan diatas dapat dilihat perbedaan antara hasil pengujian dengan hasil pencarian dengan rumus. Pada saat pengujian alat pada daya 40 watt didapatkan arus 0,13 A, tetapi setelah dihitung dengan menggunakan rumus daya maka didapatkan hasil sebsear 0,18 A, selisih tidak bigitu jauh . 


\section{Analisis Pengujian Sensor Tegangan}

Pengujian ini bertujuan untuk mengetahui apakah sensor arus dapat melakukan sensing tegangan dengan baik. Berikut merupakan data dari hasil pengujian tegangan dapat dilihat pada Gambar 18.

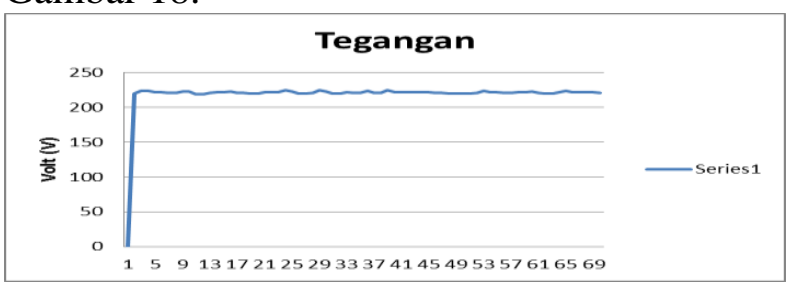

Gambar.18. Hasil Pengujian Sensor Tegangan

\section{Pengujian Modul nRF24L01}

Pengujian modul nRF24L01 bertujuan untuk mengetahui apakah modul nRF24L01 dapat bekerja sesuai dengan yang diharapkan sehingga dapat melakukan komunikasi serial antar sensor node dan master node.

Berikut adalah langkah-langkah pengujian modul nRF24L01 :

1. Membuka aplikasi arduino untuk menuliskan program ke dalam lembaran kerja arduino. Program yang telah dituliskan dapat dilihat pada Gambar.19

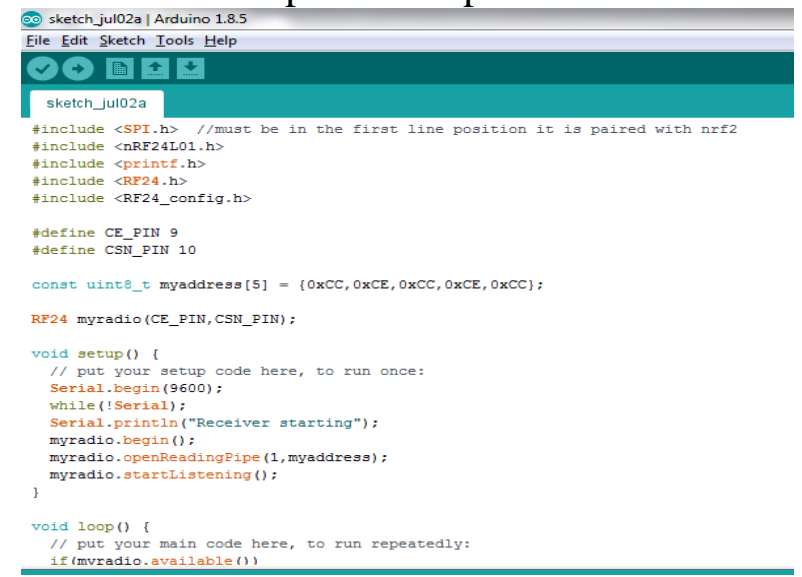

Gambar.19. Pengujian Modul nRF24L01 dengan Arduino

2. Setelah program ditulis dan di upload ke arduino, sinyal komunikasi yang dihasilkan oleh komunikasi serial antar node dapat dilihat pada serial plotter di menu bar LCD akan menampilkan karakterdan parameter-parameter energi listrik sesuai dengan program yang telah dibuat. Hasil pengujian LCD dapat dilihat pada gambar 20

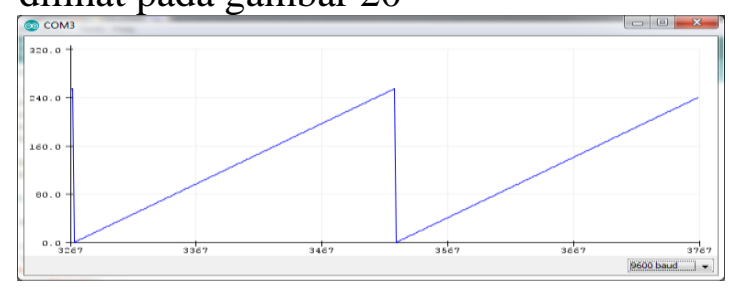

Gambar.20. Data Penerima Modul nRF24L01

Berikut merupakan data dari hasil pengujian modul nRF24L01 dapat dilihat pada Tabel 1.

Tabel 1. Data hasil pengujian Modul nRF24L01

\begin{tabular}{ccc}
\hline No & Jarak Koneksi $(\mathrm{m})$ & Status Koneksi \\
\hline 1 & 4 & Terkoneksi \\
2 & 8 & Terkoneksi \\
3 & 12 & Terkoneksi \\
4 & 16 & Terkoneksi \\
5 & 18 & Terkoneksi \\
6 & 23 & Terkoneksi \\
7 & 30 & Terkoneksi \\
8 & 35 & Terkoneksi \\
9 & 45 & Terkoneksi \\
10 & 55 & Terkoneksi \\
11 & 60 & Terkoneksi \\
12 & 65 & - \\
13 & 70 & - \\
\hline
\end{tabular}

\section{Pengujian Pengujian LCD}

Pengujian LCD bertujuan untuk mengetahui apakah LCD sudah bekerja sesuai dengan yang diharapkan sehingga dapat menampilkan karakter dan parameterparameter energi listrik. Berikut adalah langkah-langkah pengujian LCD :

1. Membuka aplikasi arduino untuk menuliskan program ke dalam lembaran kerja arduino. Program yang telah dituliskan dapat dilihat pada Gambar.21 


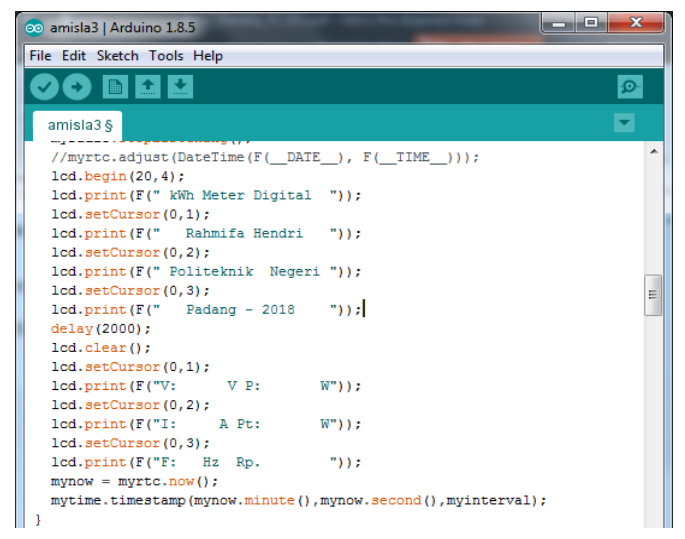

Gambar .21. Pengujian LCD dengan Arduino

2. Setelah program ditulis dan di upload ke arduino, maka LCD akan menampilkan karakter dan parameter-parameter energi listrik sesuai dengan program yang telah dibuat. Hasil pengujian LCD dapat dilihat pada gambar 22 .

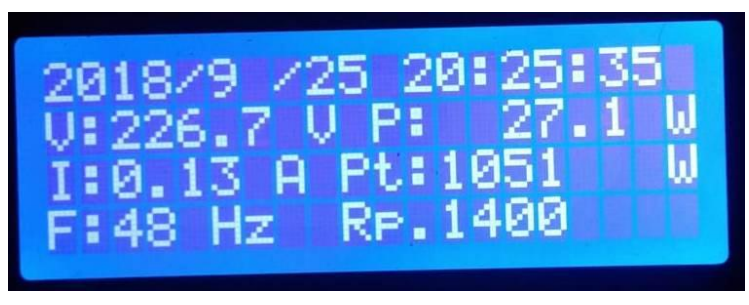

Gambar.22. Tampilan LCD

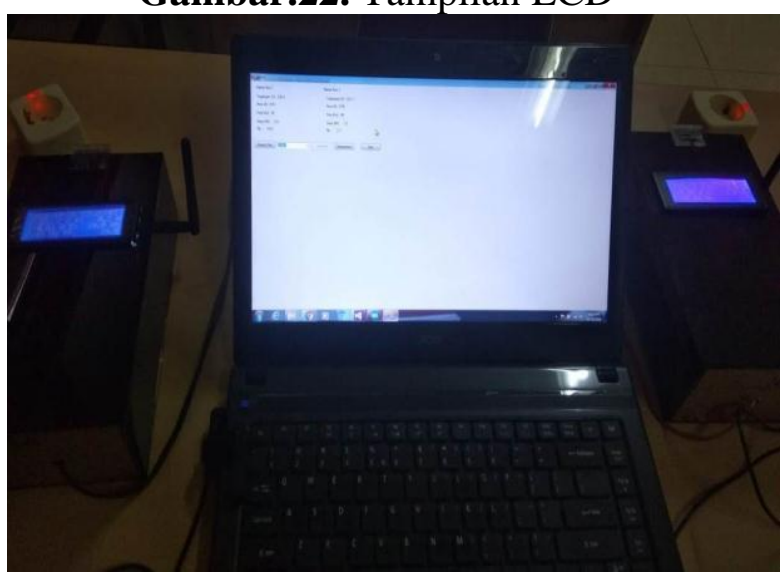

Gambar .23. Perangkat terhubung ke Laptop

\section{Prinsip Kerja Alat}

Pada Alat perancangan dan implementasi Wireless Sensor Network yang telah dibuat menggunakan arduino nano sebagai sistem minimum untuk mengendalikan semua komponen- komponen yang tersimpan pada sistem dan sebagai pengolah data dari input dan akan dikeluarkan melalui output display dan transmitter yang akan mengirimkan data ke receiver. Alat ini bekerja berdasarkan input dan perintah yang telah di program melalalui mikrokontroler,.

Dalam pembuatan alat perancangan dan implementasi Wireless Sensor Network pada alat ukur energi listrik dibuat menggunakan tiga buah input yaitu Sensor Arus, Sensor Tegangan dan Konverter frekuensi ke Tegangan. Sensor arus berfungsi sebagai pendeteksi arus yang mengalir dalam rangkaian elektronika menggunakan ZMCT103c memiliki 1:1000 lilitan medan magnetic disekitar arus kemudian dikonversi menjadi tegangan yang linear dengan perubahan arus. Nilai dari sensor arus akan menjadi input untuk mikrokontroler yang kemudian akan diolah. Mikrokontroler hanya mampu menerima tegangan sebesra $5 \mathrm{~V}$. keluaran dari sensor arus ini masih berupa sinyal tegangan AC, untuk dapat diolah oleh mikrokontroler maka sinyal tegangan AC ini di searahkan menggunakan signal conditioning menggunakan LM358. Dimana sinyal AC akan dirubah menjadi sinyal DC dan dikondisikan ke bentuk sinyal sesuai dengan kebutuhan proses selanjutnya.

Sensor tegangan menggunakan transformator tegangan sebagai penurun tegangan dari 220 ke 5 Volt AC kemudian disearahkan menggunakan signal conditioning untuk mengubah tegangan $\mathrm{AC}$ ke tegangan DC, kemudian di filter setelah itu masuk kerangkaian pembagi tegangan untuk menurunkan tegangan, tegangan yang dihasilkan tidak lebih dari 5 Volt DC sebagai inputan ke mikrokontroler. Kemudian untuk penguatan pada sinyal digunakan IC LM 358 yang menghasilkan sinyal baik yang linier maupun non linier terutama dalam sistem pengaturan dan pengendalian analog. Output dari sensor tegangan ini terhubung pada kaki Analog Pin 1 pada mikrokontroler.

Konverter frekuensi ke tegangan yang ditampilkan mengubah frekuensi 
gelombang yang masuk ke FIN menjadi tegangan yang keluar di $\mathrm{V}$ out pada LM2917. Sinyal yang telah dikonverter kemudian akan masuk ke analog input pada mikrokontroler yang terhubung ke Analog pin 2. Sinyal analog akan dikonversi menjadi nilai digital dengan ADC pada mikrokontroler sehingga dapat diproses dengan metode yang telah ditentukan dalam mikrokontroler. Tegangan DC yang dihasilkan mewakili frekuensi yang terbaca. R3 pada Gambar.12 berfungsi sebagai pembatas arus diode zener internal sedangkan R1 dan D1 sebagai clipper yang akan memotong tegangan negative gelombang sinus dari sekunder transformator step down yang masuk ke FIN dan membentuk gelombang kotak.

Setelah semua data masuk ke mikro maka data tersebut akan diolah dalam bahasa program dengan memasukan rumus parameter-parameter lisrik yang digunakan untuk mendapatkan nilai Tegangan, Arus, Frekuensi, Daya Nyata, Daya Total, dan nilai tarif energi listrik dalam nilai rupiah. Data parameter-parameter energy listrik tersebut akan di tampilkan pada display.

Setelah menampilkan data node sensor pada LCD maka data tersebut akan dikirim menggunakan modul nRF24L01 sebagai transceiver dan di terima oleh receiver pada node master. Data tersebut akan diolah oleh mikro dan akan dikirim ke PC/laptop.

\section{SIMPULAN}

Setelah melakukan tahap perancangan dan pembuatan sistem keudian dulanjutkan dengan tahap pengujian dann analisa. Maka dapat diambil kesimpulan sebagai berikut :

1. Implementasi alat ini adalah dalam rangka transparansi dan memberikan informasi beban per-kWh kepada penghuni kos dengan menggunakan sistem Wiereless Sensor Network sebagai komunikasi serial.

2. Hasil pengujian menunjukan komunikasi antar node dengan menggunakan modul nRF24L01 mampu bekerja dengan baik karena tiap node dapat berkomunikasi dengan mengirim dan menerima data.

3. Alat ini dapat memberikan informasi parameter-parameter energi listrik dan menampilkan harga dalam Rupiah yang mesti dibayar oleh penghuni kos.

\section{SARAN}

Sebagai saran pengembangan ada beberapa hal yang dapat diperbaiki dari penelitian ini yaitu dari hasil rancangan yang telah dilakukan maka diharapkan alat ukur ini dapat terkoneksi internet dan menggunakan database sebagai penyimpanan data pemakaian listrik selama 1 bulan serta bisa digunakan sebagai pengontrolan pemutusan daya listrik apabila terjadi penunggakan listrik

\section{DAFTAR PUSTAKA}

[1] Af'idah, Dwi Intan et all.(2014).’Perancangan Jaringan Sensor Nirkabel (JSN) untuk Memantau Suhu dan Kelembaban Menggunakan nRF24L01+".2.4. (eISSN:2338-0403) 268

[2]. Qiang, Cheng.(2014).”A Forest Early Fire Detection Algorithm Based on Wireless Sensor Network". 166.3,7379

[3]. Sakhinatul Putri,Y. Suryono . Endro Suseno,J.(2017)." Wireless sensor system untuk pengukuran daya listrik panel surya". Youngster Physics Journal,6.3,221-228

[4]. Putu Mastawan Eka Putra,I.G, Darminta,I.K,(2017)," Monitoring penggunaan daya listrik sebagai implementasi internet of things berbasis ESP8266", Prosiding Sentrinov,3,313-327

[5]. Damar Aji,A. Dwiyaniti,M. Nitisasmita,K.M,(2015)." $\quad$ Prototipe sistem pencatatan kwh meter otomatis berbasis wireless zigbee",Politeknologi,14.2

[6]. Sudibyo S,H. Arum W,A. Gde Dharma Nugraha. Wibisono,G.(2015)." Rancang Bangun Sistem Lampu Jalan Pintar Nirkabel Berbasis Teknologi 
Zigbee", TESLA,17.1, 45-51

[7]. Harun Arrosyid,M. Tjahjono,A. Sunarno,E . "Implementasi Wireless

Sensor Network Untuk Monitoring Parameter Energi Listrik Sebagai Peningkatan Layanan Bagi Penyedia Energi Listrik"(PENS)Surabaya

[8]. Fitriandi, Afrizal et all.(2016)."Rancang Bangun Alat Monitoring Arus dan Tegangan Berbasis Mikrokontroler dengan SMS Gateway", 10.2, 90-91

[9]. Ilmi, AA.(2014).’Rancang Bangun Aplikasi Monitoring Sebagai Informasi Gas Karbon Monoksida Pada Jaringan Sensor Nirkabel. Manajemen Informatika \& Teknik Komputer Surabaya", STIKOM Surabaya.

[10]. Kadir, Abdul.(2013).'Panduan Parkatis mempelajari Aplikasi Mikrokontroler dan Pemogramannya Menggunakan Arduino".Yogyakarta : ANDI

[11]. Sunanda, Wahri., Irwan Dinata.(2014).'Penerapan Perangkat Wireless Monitoring Energi Listrik Berbasis Arduino dan Internet". 4.2 ISSN: 2089-2020.

[12]. Wibowo, Agung.(2017).'Biaya Pasang Baru Listrik".[Online]. Tersedia: https://infopln.com/2017/09/05/biayapasang-baru-listrik/. [16 Maret 2018] 